\title{
EFFECTIVENESS OF BIOACTIVE COMPOUNDS IN AMENDING THE SOIL INFESTED WITH SOIL-BORNE Ralstonia solanacearum OF POTATO
}

\author{
Karim, Z. and M. S. Hossain ${ }^{1}$ \\ Plant Pathology Division, Bangladesh Agricultural Research Institute (BARI), Gazipur 1701, \\ Bangladesh; ' Department of Entomology, Sher-e-Bangla Agricultural University, Dhaka, Bangladesh
}

\begin{abstract}
Three natural bioactive compounds, viz. cow dung, bee propolis and turmeric powder were applied to amend the Ralstonia solanacearum infested soil of potato. Sun dried cow dung @ 30 t/ha, aqueous extraction of turmeric powder @ $30 \mathrm{~kg} / \mathrm{ha}$ and propolis @ 5 lit/ha were applied to the inoculated soil by mixing with field soil in SAU (Dhaka) and BARI (Gazipur). Data on $\mathrm{pH}$, organic matter, total cfu/ml and avirulent $\mathrm{cfu} / \mathrm{ml}$ of the treatment applied soil and per cent disease index (PDI) of bacterial wilt of potato were recorded. Significant difference in soil $\mathrm{pH}$ and per cent organic matter (OM) occurred in all the amended soil as compared to control. A decreased total $\mathrm{cfu} / \mathrm{ml}$ of $R$. solanacearum occurred in all the treated soil, but propolis $\left(8.2 \mathrm{X} 10^{7}\right)$ and cow dung $\left(1.1 \times 10^{8}\right)$ showed the lowest count. However, in increasing the avirulent count of $R$. solanacearum, turmeric powder $\left(1.8 \times 10^{9}\right)$ showed the highest count compared to other amended soil. Significant disease reduction over control was also observed in all the treatments, but propolis $(45.65 \%)$ and turmeric powder $(43.48 \%)$ showed the best results in wilt disease reduction.
\end{abstract}

Key words: Bacterial wilt; Bioactive compound; Potato; R. solanacearum; Soil amendment.

\section{INTRODUCTION}

Among the soil-borne pathogens, the bacterial species Ralstonia solanacearum (Smith 1896) is the most destructive one that affects potatoes in temperate, subtropical and tropical regions throughout the world by causing wilt or brown rot disease. It is responsible for an estimated loss of US \$1 billion each year and, the disease has been estimated to affect three million farm families for about 1.7 million hectares of potatoes approximately in 80 countries (Champoiseau et al. 2009). Yield losses due to the disease vary from 33 to $90 \%$ in the potato growing areas of the world (Elphinstone 2005). Direct yield losses caused by $R$. solanacearum depend on the host, cultivar, climate, soil type, cropping pattern and strain. In India, this disease causes 50\% crop loss in a regular manner and up to $75 \%$ losses in some areas of Karnataka (Gadewar et al. 1991). Bangladesh is the $7^{\text {th }}$ top producer of potato in the world by producing 86.03 lakh tons (Karim et al. 2020). More than $30 \%$ of potato crops are affected in this country by $R$. solanacearum, with over $14 \%$ yield reduction (Elphinstone 2005).

In Bangladesh, $R$. solanacearum incidence was recorded 9.07\% in Jamalpur area, 19.98\% in Nilphamari area and 22.65\% in Munshigonj area (Ahmed et al. 2013). Nonetheless, Russia has imposed a temporary ban on the entry of the potatoes from Bangladesh in May 2015 on food safety grounds after detecting the bacteria, $R$. Solanacearum (Karim et al. 2018). Controlling the pathogen with chemicals is difficult; antibiotics is not a safe option to be considered, because it hardly showed any effect (Farag et al. 1982). Moderate to highly resistant potato varieties have been released, but, the high frequency of latent infection in tubers is still a major problem. Further, the resistant cultivars are not adapted to different agro-climatic zones and are not effective against all the strains of the pathogen (Virupaksh et al. 2012). Due to the biological nature of "heterogeneous species complex" (capable of showing higher variability in biochemical properties in different type of environment), efficient transmissibility (overwinters in diseased plant debris, propagative organs, such as tubers, rhizomes, ginger rhizomes or banana suckers, or on the seeds of some crops like capsicum and tomato, also in the rhizosphere of weed hosts e.g. Solanum dulcamara, S. nigrum etc., and in aquatic habitats and contaminated irrigation water), extensively wide host range (over 200 species) and world-wide distribution, $R$. solanacearum became 
very successful to compromise the barriers of traditional management practices (Karim 2017). So, in management of bacterial wilt, the main components remained- the use of healthy seed and planting in clean soils (Choudhary et al. 2018). But, there is no $100 \%$ effective method massively practiced by the farmers in the world and suppression of this soil-borne pathogen is an important consideration for exporting potatoes.

However, soil amendment with antimicrobial compounds (organic) has found effective against soil borne pathogens (Chen et al. 2020) and bioactive compounds were observed to be effective in controlling $R$. solanacearum virulence (Sharma and Kumar 2009, Narasimha et al. 2015). Narasimha et al. (2015) found that $10 \%(\mathrm{w} / \mathrm{v})$ turmeric powder produced an inhibition zone from 15 to $25 \mathrm{~mm}$ against several virulent strains of $R$. solanacearum.

The concentration of bee propolis was studied as antibacterial agent and higher concentration of propolis was found to produce greater inhibition zones against both Gram negative type and Gram positive type bacteria (Rahman et al. 2010). Bee propolis is rich in flavonoids and phenolics that is why it exhibits antibacterial properties (Miorin et al. 2003). Cow dung was found to contain antibiotic agents showing higher effectiveness against both Gram negative and Gram positive type bacteria; the presence of $\mathrm{K}, \mathrm{Na}, \mathrm{Mg}$ and many other elements were observed at higher level in cow dung (Waziri and Suleiman 2013, Shrivastava et al. 2014). Therefore, the study was conducted to manage the soil-borne $R$. solanacearum of potato by using those elements as soil amendment in infested soil.

\section{MATERIAL AND METHODS}

To observe the effect of natural bioactive compounds as soil amendment against bacterial wilt of potato- turmeric powder, propolis and cow dung were used following Karim et al. (2020) in Sher-eBangla Agricultural University (SAU), Dhaka and Plant Pathology Division, Bangladesh Agricultural Research Institute (BARI), Gazipur. The study was conducted in Sher-e-Bangla Agricultural University (SAU) and Plant Pathology Laboratory, Bangladesh Agricultural Research Institute (BARI) during the robi season of 2020-2021. Bioactive compounds were prepared comparing the studies of Silva et al. (2005) and, Ibanez and Blazquez (2021). Treatments were applied to inoculated soil as soil amendment and data on per cent disease index (PDI) was recorded. Host reactions were recorded at every 4th day starting from 4th to 28th day after inoculation using the 0-5 scale of Ateka et al. (2001). The degrees of infection were recorded as $0=$ no visible symptom, $1=$ one leaf wilted, $2=$ two or three leaves wilted, $3=$ all except top two or three leaves wilted, $4=$ all leaves wilted and $5=$ dead (collapsed).

Soil test was performed to record $\mathrm{pH}$ and $\mathrm{OM}(\%)$ to understand the effect of bioactive compounds on soil health. For soil test, treatments were applied to the potato field soil and wet virgin soil of BARI and, newly transferred composted soil of SAU. After that soil samples were taken $(0-15 \mathrm{~cm}$ depth) from those treated and non-treated plots. Then the samples were analyzed in the Soil Science Laboratory, BARI. Cfu/ml per $\mathrm{g}$ of soil was counted for total cfu count and avirulent cfu count to understand the bacterial response to those compounds. Soil was inoculated @ $10^{8} \mathrm{cfu} / \mathrm{ml}$ of $R$. solanacearum in the sick plot. Counting $\mathrm{cfu} / \mathrm{ml}$ of bacteria in per $\mathrm{g}$ of soil was done following Kelman (1954). PDI, total and avirulent $\mathrm{cfu} / \mathrm{ml}$ (in colony counter) was calculated by using the following formulae (Ayana et al. 2011, Pradhanang et al. 2000):

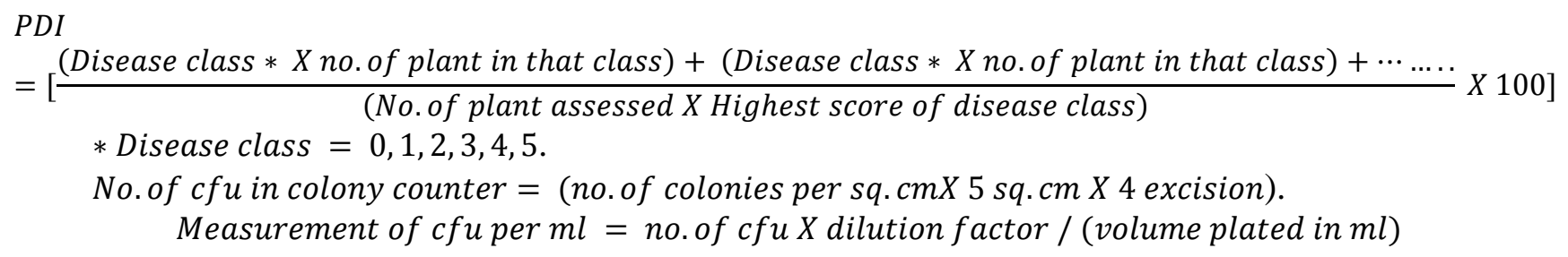


Commercially purified turmeric powder and propolis solutions soaked overnight in hot water containing a limited amount of $\mathrm{NaCl}$ were used in the experiment for better release of alkaloids and flavonoids following Mukophadhyay et al. (1982), Araujo and Leon (2001), Miorin et al. (2003), Deb et al. (2013) and Saponjac et al. (2019). Because Deb et al. (2013) reported from the laboratory test that aqueous extract of turmeric (Curcuma longa) was found to contain alkaloid, flavonoids and amino acids, whereas the ethanolic extract of it showed just flavonoids and amino acids except alkaloids. And Mukophadhyay et al. (1982) studied the activity of curcumin and its analogues, viz. sodium curcuminate, diacetyl curcumin, triethyl curcumin, and tetrahydro curcumin. They revealed that sodium curcuminate was more water-soluble than other curcumin analogues; and it was supported by Araujo and Leon (2001).

\section{Preparation and application of the bioactive compounds}

Aqueous extraction of turmeric powder $\left(\mathrm{T}_{4}\right)$ was prepared @ $30 \mathrm{~kg} / \mathrm{ha}$ and mixed with recommended cow dung manure @ 30 ton/ha which was then mixed with field soil @ 2:1 ratio to be applied in the $R$. solanacearum inoculated pit of potato field. Aqueous extraction of propolis $\left(\mathrm{T}_{3}\right)$ was prepared @ 5 lit/ ha and mixed with recommended cow dung manure @ 30 ton/ha which was then mixed with field soil @ 2:1 ratio to be applied to the $R$. solanacearum inoculated pit of potato field. For cow dung treatment $\left(\mathrm{T}_{2}\right)$, it was applied @ 30 ton/ha which was previously sun dried and mixed with field soil (@ 2:1 ratio) to be applied to the inoculated pit of potato field in addition with the recommended cow manure dose to achieve good microbial activity following Manyi-Loh et al. (2016) and a control treatment ( $\left.\mathrm{T}_{1}\right)$ was kept as no amendment of soil.

\section{Aqueous extraction preparation}

To soak the compounds overnight, turmeric powder $\left(\mathrm{T}_{4}\right)$ and propolis $\left(\mathrm{T}_{3}\right)(@ 3 \mathrm{~g} / \mathrm{lit}$ and $0.5 \mathrm{ml} / \mathrm{lit}$, respectively) were mixed in hot water containing a limited amount of $\mathrm{NaCl}$ (compounds: $\mathrm{NaCl} @ 3: 1$ ratio w/w). Those prepared compounds were incorporated with the cow dung manure on the next day after soaking and mixed with field soil (@2:1 ratio) and applied as soil amendment to the inoculated potato field. Data were subjected to ANOVA by using Analysis Tool Pak and significant difference among the treatments was done by Least Significant Difference Test (LSD) at probability levels of $\mathrm{P}=0.05$ following Arsham (2020).

\section{RESULTS AND DISCUSSION}

A significant difference was observed in case of soil $\mathrm{pH}$ and per cent organic matter among treated and non-treated soils. In potato field soil at BARI, the highest $\mathrm{pH}$ was observed in propolis- $\mathrm{T}_{3}(7.4)$ amended soil which was followed by turmeric powder- $\mathrm{T}_{4}$ (7.3) and cow dung- $\mathrm{T}_{2}(7.1)$, and the highest per cent of OM was also recorded in propolis- $\mathrm{T}_{3}(2.12)$ which was followed by cow dung- $\mathrm{T}_{2}(1.75)$ and turmeric powder- $\mathrm{T}_{4}$ (1.52) as compared to control- $\mathrm{T}_{1}$ (6.7 and 1.4, respectively). In the wet virgin soil at BARI, it was also found that the highest $\mathrm{pH}$ was occurred in propolis- $\mathrm{T}_{3}$ (8.3) which was followed by both turmeric powder- $\mathrm{T}_{4}(8.2)$ and cow dung- $\mathrm{T}_{2}$ (8.2), and the highest percent of $\mathrm{OM}$ was also recorded in propolis- $\mathrm{T}_{3}$ (1.9) which was followed by turmeric powder- $\mathrm{T}_{4}$ (1.8) and cow dung- $\mathrm{T}_{2}$ (1.7) whereas the lowest of both (8.0 and 1.4, respectively) was recorded in non-treated control (Table 1). However, no difference in $\mathrm{pH}$ and percent of $\mathrm{OM}$ was observed to occur among the treated, and between the treated and control of newly transferred composted soil of Sher-e- Bangla Agricultural University, Dhaka (Table 1).

In case of total $\mathrm{cfu} / \mathrm{ml}$ per gram of amended soil, the highest total $\mathrm{cfu} / \mathrm{ml}$ was recorded in control- $\mathrm{T}_{1}$ $\left(2.7 \times 10^{8}\right)$ whereas the lowest of that was in propolis- $\mathrm{T}_{3}\left(8.2 \times 10^{7}\right)$ followed by cow dung- $\mathrm{T}_{2}(1.1 \mathrm{X}$ $\left.10^{8}\right)$ and turmeric powder- $\mathrm{T}_{4}\left(1.7 \times 10^{8}\right)$. So, the propolis and cow dung treatments were comparatively 
better in decreasing the total cfu count of $R$. solanacearum infested soil. But, in case of avirulent cfu/ml of per gram soil, amendment with turmeric powder- $\mathrm{T}_{4}\left(1.8 \times 10^{9}\right)$ showed the highest $\mathrm{cfu} / \mathrm{ml}$ as compared to the lowest case in control- $\mathrm{T}_{1}\left(5.9 \times 10^{8}\right)$.

Table 1. Effects of natural bioactive compounds on soil pH and organic matter.

\begin{tabular}{l|ccc|ccc}
\hline \multirow{2}{*}{ Treatments } & \multicolumn{3}{|c|}{$\mathbf{p H}$} & \multicolumn{3}{c}{ OM (\%) } \\
\cline { 2 - 7 } & $\begin{array}{c}\text { Potato } \\
\text { field soil }\end{array}$ & $\begin{array}{c}\text { Wet } \\
\text { virgin soil }\end{array}$ & $\begin{array}{c}\text { Newly transferred } \\
\text { composted soil }\end{array}$ & $\begin{array}{c}\text { Potato } \\
\text { field soil }\end{array}$ & $\begin{array}{c}\text { Wet } \\
\text { virgin soil }\end{array}$ & $\begin{array}{c}\text { Newly transferred } \\
\text { composted soil }\end{array}$ \\
\hline $\mathrm{T}_{1}$ - Control & 6.7 & 8 & 8.6 & 1.4 & 1.4 & 1.7 \\
$\mathrm{~T}_{2}$ - Cow dung (@ 30 t/ha) & 7.1 & 8.2 & 8.6 & 1.75 & 1.7 & 1.7 \\
$\mathrm{~T}_{3}$ - Propolis (@ 5.0lit/ha) & 7.4 & 8.3 & 8.6 & 2.12 & 1.9 & 1.7 \\
$\mathrm{~T}_{4}$ - Turmeric powder (30kg/ha) & 7.3 & 8.2 & 8.6 & 1.52 & 1.8 & 1.7 \\
\hline $\mathrm{P}$-value (0.05)* & 0.00012 & 0.00013 & -- & $5.7 \mathrm{E}-05$ & 0.00063 & -- \\
\hline
\end{tabular}

Treatment with turmeric powder- $\mathrm{T}_{4}$ followed by propolis- $\mathrm{T}_{3}\left(1.2 \mathrm{X} 10^{9}\right)$ and cow dung- $\mathrm{T}_{2}(1.0 \mathrm{X}$ $\left.10^{9}\right)$ in the same count which were statistically similar to each other. Thus, turmeric powder was the best in increasing the avirulent cfu count of those amended soil with bioactive compounds (Table 2 and Fig. 1).

Table 2. Effects of natural bioactive compounds on cfu per ml per gram of treated and control soil.

\begin{tabular}{lcc}
\hline Treatment & $\begin{array}{c}\text { Total cfu/ml } \\
\text { (per g of soil) }\end{array}$ & $\begin{array}{c}\text { Avirulent cfu/ml } \\
\text { (per g of soil) }\end{array}$ \\
\hline $\mathrm{T}_{1^{-}}$Control & $2.7 \times 10^{8} \mathrm{a}$ & $5.9 \times 10^{8} \mathrm{~d}$ \\
$\mathrm{~T}_{2}$ - Cow dung (@30 t/ha) & $1.1 \times 10^{8} \mathrm{c}$ & $1.0 \times 10^{9} \mathrm{bc}$ \\
$\mathrm{T}_{3}$ - Propolis (@ 5 lit/ha) & $8.2 \times 10^{7} \mathrm{~cd}$ & $1.2 \times 10^{9} \mathrm{~b}$ \\
$\mathrm{~T}_{4}$ - Turmeric powder (@30 kg/ha) & $1.7 \times 10^{8} \mathrm{~b}$ & $1.8 \times 10^{9} \mathrm{a}$ \\
\hline $\mathrm{p}$-value (0.05) & $0.000024^{*}$ & $0.00009^{*}$ \\
LSD value & 0.16 & 0.16 \\
$\%$ CV & 26.71 & 38.35 \\
\hline
\end{tabular}

Here, * $=\mathrm{p}$ value for within treatment $(0.000024)$ is significant at $5 \%$ level.

The soil application of the sun dried cow dung- $\mathrm{T}_{2}$, propolis- $\mathrm{T}_{3}$ and turmeric powder- $\mathrm{T}_{4}$ showed a significant reduction of PDI in different treatment amended soils as compared to control $\left(\mathrm{T}_{1}\right)$.

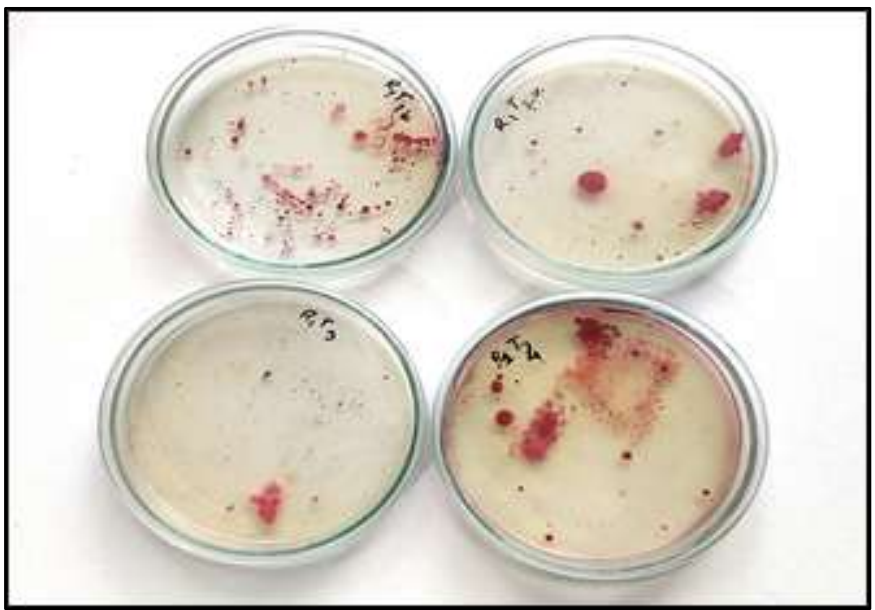

$\mathbf{a}$

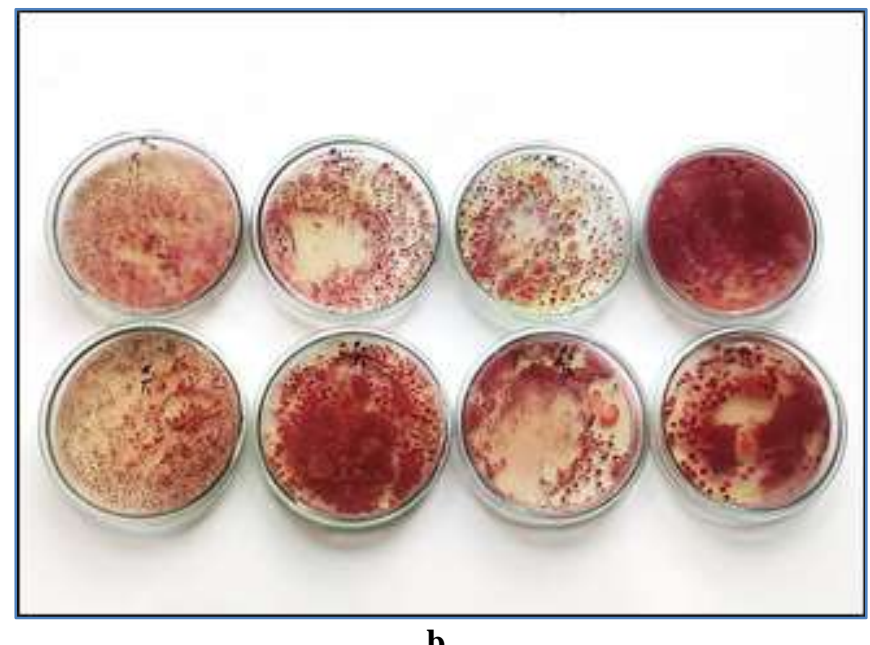

b

Fig. 1. Different petri dishes: a. Control- $\mathrm{T}_{1}$, Cow dung- $\mathrm{T}_{2}$, Propolis- $\mathrm{T}_{3}$ and Turmeric powder- $\mathrm{T}_{4}$ showing cfu/ml of per gram treated and control soil without inoculation; and b. with inoculation of $R$. solanacearum @ $10^{8} \mathrm{cfu} / \mathrm{ml}$. 
The highest PDI was recorded in control- $\mathrm{T}_{1}(61.33 \%)$ whereas the lowest of that was observed in propolis- $\mathrm{T}_{3}(33.33 \%)$ which was followed by turmeric powder- $\mathrm{T}_{4}(34.67 \%)$ and cow dung- $\mathrm{T}_{2}(40.00 \%)$ and the last two were statistically insignificantly in respect of percent disease index. So, the highest disease reduction occurred in case of propolis- $\mathrm{T}_{3}(45.65 \%)$ which was followed by turmeric powder- $\mathrm{T}_{4}$ $(43.48 \%)$ and the lowest was recorded in cow dung- $\mathrm{T}_{2}(34.78 \%)$ over control (Table 3$)$.

Table 3. Effect of natural bioactive compounds on PDI and percent disease reduction of treated and control soil.

\begin{tabular}{lcc}
\hline Treatment & PDI (Percent Disease Index) & \% Disease Reduction \\
\hline $\mathrm{T}_{1}$ - Control & $61.33 \mathrm{a}(51.85)$ & 0.00 \\
$\mathrm{~T}_{2}$ - Cow dung (@ 30 t/ha) & $40.00 \mathrm{~b}(39.19)$ & 34.78 \\
$\mathrm{~T}_{3}$ - Propolis (@ 5 lit/ha) & $33.33 \mathrm{bcd}(35.22)$ & 45.65 \\
$\mathrm{~T}_{4}$ - Turmeric powder (@ 30kg/ha) & $34.67 \mathrm{bc}(35.88)$ & 43.48 \\
\hline P- value (0.05) & $0.0028^{*}$ \\
\% CV & 22.79 \\
\hline
\end{tabular}

Here, $*=p$ value for within treatment $(0.0028)$ is significant at $5 \%$ level.

In various studies, viz. Michel and Mew (1998), Vudhivanich (2002), and Ayana et al. (2011) it has shown that using different soil amendments would minimize bacterial wilt disease caused by $R$. solanacearum; it was because no single strategy has shown $100 \%$ efficiency in controlling the disease so far. In the present study, 45.65, 43.48 and $34.78 \%$ disease reductions were observed occuring in bee propolis, turmeric powder and sun dried cow dung amended soil @ 5 litre/ha, @30 kg/ha and @30 ton/ha, respectively. In the experiment turmeric powder, propolis and cow dung containing soil amended the $R$. solanacearum infestation of potato soil and observed an increase in the avirulent count of $R$. solanacearum $\left(1.8 \times 10^{9}, 1.2 \times 10^{9}\right.$ and $1.0 \times 10^{9} \mathrm{cfu} / \mathrm{ml}$, respectively) which revealed the cause of $R$. solanacearum suppression in soil. In another study, Narasimha et al. (2015) also found that turmeric powder $(10 \% \mathrm{w} / \mathrm{v})$ produced an inhibition zone from 15 to $25 \mathrm{~mm}$ against several virulent strains of $R$. solanacearum.

Bee propolis was also studied as antibacterial agent by Rahman et al. (2010) and it was found to produce greater inhibition zones against both Gram negative type and Gram positive type bacteria. Propolis is rich in flavonoids and phenolics that is why it exhibits antibacterial properties (Miorin et al. 2003).

Cow dung was also found to contain antibiotic agents showing higher effectiveness against both Gram negative and Gram positive type bacteria by Waziri and Suleiman (2013). The presence of K, Na, $\mathrm{Mg}$ and many other elements were observed at higher level in cow dung (Shrivastava et al. 2014). Nevertheless, pathogen inactivation was observed to occur in cow manure/slurry when stored in low or moderate temperature over an extended period of time in the influence of UV radiation from sunlight by Maule (2000).

Results of the present experiment are in agreement to the above findings. In another study Sharma and Kumar (2009) applied plant extracts of asafoetida+turmeric, onion and garlic against $R$. solanacearum wilt of tomato and observed to perform well in reducing the primary inocula which also supported the present findings. Ji et al. (2005) suggested the use of thymol (a plant-derived chemical) to reduce the disease incidence of bacterial wilt. Akter et al. (2021) reported that Trichoderma harzianum individually or in combination with Furadan $3 \mathrm{G}$ and poultry manure reduced the disease well when applied to soil against the bacterial wilt complex of eggplant. Liu et al. (2015) also observed bio-organic fertilizer to enhance the soil suppressiveness against bacteria wilt of tomato. The authors also found an increase in soil $\mathrm{pH}$ in amendment treated soil which was parallel to the findings of Michel and Mew (1998) who used soil amendment composed of urea (200 kg of N per ha) and CaO (5,000 kg/ha) against 
the survival of $R$. solanacearum in four types of soil and, found an initial decrease in a soil with higher $\mathrm{pH}$ which resulted a significantly $(\mathrm{P}<0.001)$ lower pathogen population at one week after amending the soil.

However, it was also found that within three weeks after application of the soil amendments, either it caused an initial decrease, or a final decline, or no change in the pathogen population depending on the particular soil type among the four types of Philippine soil. Application of the treatments showed a significant reduction of Ralstonia solanacearum $\mathrm{cfu} / \mathrm{ml}$ of soil and enhancement of soil organic matter and $\mathrm{pH}$.

\section{ACKNOWLEDGEMENTS}

We acknowledge Yildirim Plastik (ApiMaye Beekeeping) for supporting us with bee propolis and other necessary assistance.

\section{REFERENCES}

Ahmed, N. N., M. R. Islam, M. A. Hossain, M. B. Meah and M. M. Hossain. 2013. Determination of races and biovars of Ralstonia solanacearum causing bacterial wilt disease of potato. J Agril Sci. 5: 86-93.

Akter, N., M. R. Islam, M. B. Hossain, M. N. Islam, S. R. Chowdhury, S. Hoque, R. H. Nitol and R. Tasnin. 2021. Management of wilt complex of Eggplant (Solanum melongena L.) caused by Fusarium oxysporum, Ralstonia solanacearum and Meloidogyne spp. Am. J. Plant Sci. 12: 11551171.

Arsham, H. 2020. Excel for statistical data analysis. John Hopkins University, Baltimore, USA. 37 pp.

Araujo, C. A. C. and L. L. Leon. 2001. Biological activities of Curcuma longa L. Mem Inst Oswaldo Cruz, Rio de Janeiro. 96(5): 723-728.

Ateka, E. M., A. W. Mwang'Ombe and J. W. Kimenju. 2001. Reaction of potato cultivars to Ralstonia solanacearum in Kenya. Afr. Crop Sci. J. 9: 251-256.

Ayana, G., C. Fininsa, S. Ahmed and K. Wydra. 2011. Effects of soil amendment on bacterial wilt caused by Ralstonia solanacerum and tomato yields in Ethiopia. J. Plant Prot. Res. 51(1): 72-76.

Champoiseau, P. G., J. B. Jones and C. Allen. 2009. Ralstonia solanacearum race 3 biovar 2 causes tropical losses and temperate anxieties. Plant Health Progress. pp. 1-10.

Chen, K., R. A. A. Khan, W. Cao and M. Ling. 2020. Sustainable and ecofriendly approach of managing soil-borne bacterium Ralstonia solanacearum (Smith) using dried powder of Conyza canadensis. Pathogens. 9(5): 327.

Choudhary, D. K., S. U. Nabi, M. S. Dar and K. A. Khan. 2018. Ralstonia solanacearum: A wide spread and global bacterial plant wilt pathogen. J. Pharmacog. Phytochem. 7(2): 85-90.

Deb, N., P. Majumdar and A. K. Ghosh. 2013. Pharmacognostic and phytochemical evaluation of the rhizomes of Curcuma longa Linn. J. Pharma Sci. Tech. 2(2):81-86.

Elphinstone, J. G. 2005. The current bacterial wilt situation: A global overview. In: C. Allen, P. Prior, and A. C. Hayward (eds.). Bacterial Wilt: The Disease and the Ralstonia solanacearum Species Complex. APS Press, St. Paul, MN, USA., pp. 9-28.

Farag, N. S., S. M. Lashin, R. S. Abdel-All, H. M. Shatta and A. M. Seif-Elyazal. 1982. Antibiotics and control of potato black leg and brown rot diseases. Agric. Res. Rev. 60(2): 149-166. 
Gadewar, A. V., T. P. Trivedi and G. S. Sekhawat. 1991. Potato in Karnataka. Tech. Bull. 17: 33.

Ibanez, M. D. and M. A. Blazquez. 2021. Curcuma longa L. Rhizome essential oil from extraction to its agri-food applications: A review. Plants. 10(1):44.

Ji, P., M. T. Momol, S. M. Olson and P. M. Pradhanang. 2005. Evaluation of thymol as biofumigant for control of bacterial wilt of tomato under field conditions. Plant Disease. 89: 497-500.

Karim, Z., M. S. Hossain and M. M. Begum. 2018. Ralstonia solanacearum: A threat to potato production in Bangladesh. Fundam. Appl. Agric. 3(1): 407-421.

Karim, Z. 2017. Study on Phenotypic Conversion, Virulence, and Biovar Expression of Ralstonia solanacearum causing Potato Wilt and its Management. Ph.D. Thesis. Sher-e-Bangla Agricultural University, Agargaon, Dhaka-1207, Bangladesh. 198 pp.

Karim, Z., M. Chowdhury and M. S. Hossain. 2020. Management of Ralstonia solanacearum (potato wilt disease) virulence by using bioactive compounds. J. biodivers. conserv. bioresour. manag. 6(1): 65-76.

Kelman, A. 1954. The relationship of pathogenicity in Pseudomonas solanacearum to colony appearance on a tetrazolium medium. Phytopathology. 44: 693-695.

Liu, L., C. Sun, S. Liu, R. Chai, W. Huang, X. Liu, C. Tang and Y. Zhang. 2015. Bioorganic fertilizer enhances soil suppressive capacity against Bacterial Wilt of tomato. PLoS ONE. 10(4): 1-16.

Manyi-Loh, C. E., S. N. Mamphweli, E. L. Meyer, G. Makaka, M. Simon and A. I. Okoh. 2016. An overview of the control of bacterial pathogens in cattle manure. Int. J. Environ. Res. Public Health. 13(9): 1-27.

Maule, A. 2000. Survival of verocytotoxigenic Escherichia coli O157 in soil, water and on surfaces. J. Appl. Microbiol. 88: 21-23.

Michel, V. V. and T. W. Mew. 1998. Effect of a soil amendment on the survival of Ralstonia solanacearum in different soils. Phytopathology. 88: 300-305.

Miorin, P. L., N. C. J. Levy, A. R. Custodio, W. A. Bretz and M. C. Marcucci. 2003. Antibacterial activity of honey and propolis from Apis mellifera and Tetragonis caangustula against Staphylococcus aureus. J. Appl. Microb. 95: 913-920.

Mukophadhyay A, N. Basu, N. Ghatak and P. K. Gujral. 1982. Anti-inflammatory and irritant activities of curcumin analogues in rats. Agents and Actions. 12: 508-515.

Narasimha, M. K., K. Soumya and C. Srinivas. 2015. Antibacterial activity of Curcuma longa (Turmeric) plant extracts against Bacterial Wilt of tomato caused by Ralstonia solanacearum. Int. J. Sci. Res. 4(1): 2136-2141.

Pradhanang, P.M., J. G. Elphinstone and R. T. V. Fox. 2000. Sensitive detection of Ralstonia solanacearum in Soil: a comparison of different detection techniques. Plant Pathology. 49: 414422.

Rahman, M. M., A. Richardson and M. S. Azirun. 2010. Antibacterial activity of propolis and honey against Staphylococcus aureus and Escherichia coli. Afr. J. Microbiol. Res. 4(16): 1872-1878.

Saponjac V.T, G. Cetkovic, J. Canadanovic-Brunet, A. Mandic, V. Seregelj, J. Vulic and S. Stajcic. 2019. Bioactive characteristics and storage of salt mixtures seasoned with powdered cereal sprouts. Hindawi J. Chem. 2019: 1-9. 
Sharma, J. P. and S. Kumar. 2009. Management of Ralstonia wilt of tomato through microbes, plant extract and combination of cake and chemicals. Indian Phytopath. 62(4): 417-423.

Shrivastava, S., A. Mishra and A. Pal. 2014. Cow dung: A boon for antimicrobial activity. Life Sci. Leaflets. 55: 60-63.

Silva, L. V., D. L. Nelson, M. F. B. Drummond, L. Dufosse and M. B. A. Gloria. 2005. Comparison of hydro distillation methods for the deodorization of turmeric. Food Res. Int. 38: 1087-1096.

Smith, E. F. 1896. A bacterial disease of the tomato, eggplant and Irish potato caused by Bacillus solanacearum. U.S. Dept. Agr. Div. Veg. Phys. Path. Bull. 12: 1-28.

Virupaksh, U., V. U. Patil, J. Gopal and B. P. Singh. 2012. Improvement for Bacterial Wilt resistance in potato by conventional and biotechnological approaches. Agric. Res. 1(4):299-316.

Vudhivanich, S. 2002 Effect of soil amendment with urea and calcium oxide on survival of Ralstonia solanacearum, the causal agent of Bacterial Wilt or Rhizome rot of Ginger. Kasetsart J. (Nat. Sci.). 36: $242-247$.

Waziri, M. and J. S. Suleiman. 2013. Analysis of some element and antimicrobial activity of evaporated extract of cow dung against some pathogens. J. Scientific Res. 5(1): 135-141. 